\title{
Evaluating the Roles of Regional Based Political Parties in Fostering Ethnic Unity in Benishangul Gumuz Regional State, Ethiopia (Since 1991)
}

\author{
Muluneh kassa \\ Lecturer in the College of Social Science and Humanities at Assosa Universit
}

\begin{abstract}
In multi-ethnic federations which were particularly established to manage the existing diversity, the political parties should promote, preserve and protect the existing diversity and simultaneously endorse the sense of unity. Under multi-ethnic states political parties as one main actor should audaciously nurture sense of unity in diversity ideally and practically. Here, fostering ethnic unity means not only sharing identical political philosophy among individuals or groups, but it also remind as that individuals or groups may have differences in opinion and leaning. Therefore, the main purpose of this paper is to critically examining the practical role of regional based political parties in promotion of ethnic unity under contemporary Benishangul Gumuz Regional State (hereafter used as BGRS). In this regard, the author of this paper collected various empirical data through personal interviews, focus group discussions and administering survey questionnaire. Based on the information gained through various research instruments the author concluded that despite the fact that the government has recognized the creation of ethnic political parties as a positive political measure to promote every ethnic group in the country to have a sense of belonging, but in contrast, the existence of ethnic based political parties and hasty mushrooming of narrow ethno-nationalist politics has constituted one major impediment to promote unity and peaceful coexistence among various ethnic groups in BGRS. Moreover, the writer also argued that organizing political parties only through political lens of ethnicity would gradually create elevated ethnic fundamentalism, chauvinism and parochialism among politicians and individuals. And later it also opened the door for politicians and individuals to play lopsided proxy ethnic political game within the neighbouring regional states and consequently this situation tend to ethnic conflict. Thus, this kind of political party establishment road-map in the country has paved the way to series ethnic conflicts which resulted major predicaments and disunity among various ethnic groups in the country in general and regional states in particular.
\end{abstract}

Keywords: Political Party; BGRS; Ethnicity; Ethnic Unity; Ethnic Conflict; Ethnic Diversity; Politicians DOI: $10.7176 /$ RHSS/9-1-06

\section{Introduction}

Actually, in multi-ethnic federations which were particularly established to manage the existing diversity, the political parties should promote, preserve and protect the existing diversity and simultaneously endorse the sense of unity. Political parties as one main actor should audaciously nurture sense of unity in diversity ideally and practically. Therefore, this paper discusses the roles of regional based political parties particularly in promoting ethnic unity under BGRS. In this context, the first section introduces brief overview of geographic and demographic settings of the study area (BGRS). The second section introduces the panorama of the nature and dynamics of political parties and the party system in the region. The third section describes ethnic loyalty and the nature of politics in pre-BGPDP formation. The fourth section examines the nature of ethnic unity in postBGPDP formation. Moreover, this section presents and analyses the present-day roles of regional political parties and politicians in promotion of regional unity in BGRS. Finally, this paper end up with conclusion and recommendations.

\section{Brief Overview of Geographic and Demographic Settings of BGRS}

BGRS is one of the nine constituent units of the Federal Democratic Republic of Ethiopia (refer Art 47(6) of the FDRE constitution). The region is located in the Northwestern part of the country at 9017'S to 1206'N latitude and 340101 to 37041 E longitude bordering with Sudan in the West, Oromya Regional State in the East, Amhara Regional State in the North and Gambella Regional State in the South. The regional state has a total land area of $50,381 \mathrm{~km} 2$ with a total population of about 670,847 (Ethiopian Central Statistical Authority, 2007 Ethiopian census). Under current structure the region was organized with three administrative de facto Zones. Such as Asossa Zone (which incorporates Bambasi, Assosa, Oda Godere, Menge, Homosha and Sherkole Woredas), Kamashi Zone (Sedale, Agalo Meti, Kamashi, Belo-Jeganfoy and Yaso Woredas), and Metekel Zone (which incorporates Dibate, Bullen, Mandura, Dangur, Guba, Wombera and Pawe Woreda). Apart from this, MaoKomo Woreda has been recognized as special Woreda under Assosa Zone (Source: From the Researcher Field Note). 
Map 1: Administrative Map of Current BGRS (the study area)

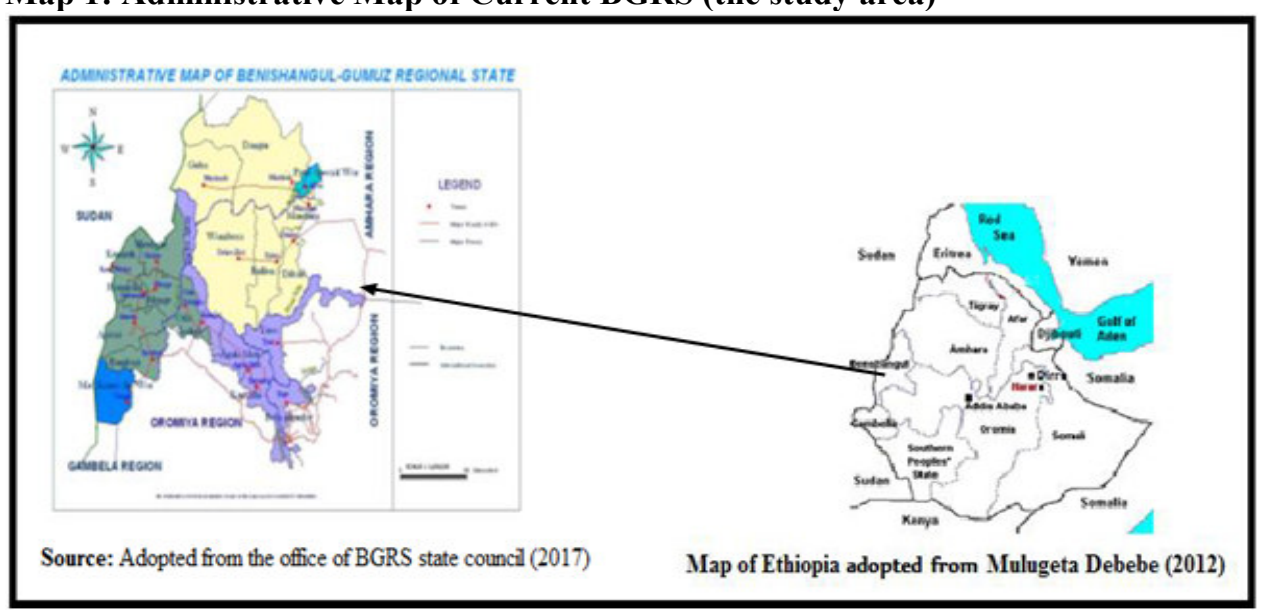

Source: Interrelated by the researcher

BGRS is home of different ethnic, cultural, linguistic and religious groups. Hence, BGRS constitution recognizes the presence of different ethnic, cultural, linguistic and religious groups under the region (see the preamble of the revised regional constitution). Besides, the regional constitution explicitly categorized the peoples of the regional state in to two broad groups. Namely ethnic groups as owner and indigenous nationalities of the region such as the Bertha, Gumuz, Shinasha, Mao and Komo, whereas other peoples of the country residing in the region as non-indigenous ethnic groups (refer Art 2 of 2002 the revised BGRS constitution).

\section{Panorama of the Nature and Dynamics of Political Parties in BGRS}

In this paper before discussing the nature and dynamics of political parties in the study area, it is essential to discuss various scholarly discourses on the meaning of political party. Indeed, numerous scholars have come up with various definitions of the concept political party. For instance, Appadorai (1968) defines a political party as a more or less organized group of citizens who act together as a political unit, with distinctive aims and opinions on the political questions of the state and who, acting together as a political unit, seek to control government. To Adeyemi (1980) political parties are associations formally organised with the explicit and declared purpose of acquiring or maintaining legal control either individually or in coalition or in electoral competition with other similar associations over the personnel and the policy of government of sovereign state (quoted in Ubani, 2014). Giovanni Sartori (1994) on the other hand explain that parties are the central, intermediate and intermediary structure between society and government and accordingly they must attempt to serve the "public interest" or the common good and "organize the chaotic public will." In a similar vein, Sigmund Neumann (1956) also stated that a political party is serves as "the great intermediary which links social forces and ideologies to official governmental institutions and relates them to political action within the larger political community" (quoted in Horowitz, 1985: 297).

According to Michael Burgess (2006: 150) political parties are vehicles and instruments of organized, vested interests that express particular values, beliefs and aspirations. They are partisan representing particular constellations of cleavage patterns and vested interests. In this case, the role of regional parties expressing territorial diversities is part and parcel of an asymmetrical party system (Bryce, Studies in History, Vol. II, 56, quoted in Michael Burgess, 2006: 220). But it doesn't mean that political parties always disregard common values and interests of the country. At the same time they might of course become vehicles of diversity and unity. In summary, based on the above scholarly explanations, it can be asserted that a political party is a group whose members propose to act in concert in the competitive struggle for political power with the major aim of promoting common public good. This power ultimately should be to pursue the interest of the group that formed the party and for public good. Therefore, political parties are the fulcrum for the struggle for power and the enunciation of doctrine and programmes for the governance of any society. In fact, as one institutional entity they should promote, preserve and protect the existing diversity and simultaneously endorse the sense of unity particularly in those federations which were fundamentally established to accommodate or manage diversity. It means that ideologies and policies concurrently promoting sense of unity in diversity should be audaciously viewed ideally and also practically by every political party based on their own country's specific context. Which means they are considered as one of the basic actors in promoting unity in diversity in multi-ethnic federations. In addition to this, in any democratic political system opposition political parties should act as unpaid researchers in their country's political setting to enhance the essence of democracy and peaceful coexistence among various cleavages. To this effect, Duchacek reminds us that democracy and federalism are always found together; federalism is the territorial dimension of democracy; genuine competition between parties is a condition for 
federalism (Duchacek, 1970).

In BGRS history, Benishangul People Liberation Movement (BPLM) was formally organized the first political party in the region which was predominantly established by members of Bertha ethnic group in 1989 in Sudan (Young, 1999). In fact, the fundamental objective why BPLM was established in the region by the Bertha people and accordingly to exercise their right of self-determination by removing Derg regime. In this regard, following the toppling of the Derg regime, BGRS was established as one of the constituent units of the contemporary Ethiopian federation by merging parts of the former Assosa, Metekel administrative regions and the current Kamahi Zone areas by proclamation No. 7/1992. Consequently, after the establishment of BGRS in 1992 all other indigenous ethnic groups of the region immediately organized their own respective independent ethnic based political parties to exercise their right of self-determination in the region. Namely Shinasha People's Democratic Movement (SPDM), Gumuz People's Democratic Organization (GPDO), Mao People's Democratic Movement (MPDM) and Komo People's Democratic Movement (KPDM).

However, in 1993 under the auspices of EPRDF these above mentioned ethnic based political parties organized into one centralized party under the dominant control of BPLM in the region, which was named as West Ethiopian People's Democratic Party (WEPDP). As clearly pointed out by Asnake Kefale (2009), BPLM did not as such succeed in maintaining its dominant position because of the prevalence of internal division among key political elites of the movement. As a result, during the formative years of the region this political division created the prompt successive replacement of regional presidential position by three different Bertha ethnic group politicians within two years (ibid). This political condition also annoyed EPRDF and forced the region to re-organize its political party structure. Accordingly, BPLM organization was replaced by Ethiopian Bertha People's Democratic Party (EBPDP) (ibid). And later, the central party (WEPDP) which was organized during the transitional period dissolved and was replaced by Benishangul-Gumuz people United Democratic Front (BGPUDF) in 1997 (Interview with former higher officials of the region, 25 June 2017, Assosa).

Generally, prior to 2010 the region was led by a common front without any regional based opposition political party, but after 2010 individual ethnic based political parties decided to make a bargain and establish one party rather than a front which is known as Benishangul-Gumuz People's Democratic Party (BGPDP). BGPUDF have no an organized party secretariat and administrative staff or employees. However, BGPDP have an organized party secretariat and administrative staff. Indeed, the current political parties' arrangement under BGRS can be divided into three categories. Such as Benishangul-Gumuz People's Democratic Party (BGPDP), the BGPDP-affiliated parties, which are EPRDF member parties and BGRS based opposition party which is known as Gumuz People Democratic Movement (GPDM). But the current situation on the ground indicates that political party structure in BGRS is characterised by the extreme asymmetry between the power of the ruling party (BGPDP), and the extreme weakness of the opposition party (GPDM) as the case of Ethiopian present-day federal level of government.

Indeed, as indicated above, in addition to BGPDP, Gumuz People Democratic Movement (GPDM) is a legally organized and registered mono-ethnic based regional political party which has competed for various elections in BGRS. Accordingly, these two regional based political parties and BGPDP-affiliated parties (such as ANDM, OPDO, TPLF and SEPDM) competed in the 2015 regional election. Actually, both BGPDP and GPDM are ethnic based regional political parties in BGRS. However, structurally BGPDP is multi-ethnic party whereas albeit GPDM's membership is open to every eligible Ethiopian citizen as per Art 12 (2) of the approved party regulation, GPDM is a mono-ethnic based political party in the region. Because the approved party's regulation and program of GPDM vibrantly shows that this party is only feel responsible for the interest of Gumuz ethnic group only without considering the interest of other ethnic groups in the region.

In a similar vein, the hereto ruling parties of all other regional states in the country in general are overwhelmingly ethnic based political parties. Because before the inception of the present-day federal political arrangement, most of ethnic based political parties early emerged as anti-Derg regime in different parts of the country. Beyond this, the Ethiopian revised political party registration proclamation No. 573/2008 has not explicitly prohibited the formation of political parties on the basis of ethnicity. Therefore, like that of other ruling regional state parties, BGPDUF or the current BGPDP declared itself as vanguard liberation movement immediately after the establishment of BGRS.

The growth of political parties naturally followed regional and ethnic divisions. One of the major parties dominated each region and the party, in turn, was dominated by the predominant ethnic group in that region. It should be remembered that the minorities in these regions responded to their dominance by the major ethnic group and their political parties by forming their own ethnic parties and demanded that states be created for them. This situation led to the proliferation of many ethnic based political parties in the country in general and regional states in particular after the military power was dismantled.

It is a fact that, in contemporary Ethiopia, all parties are supported mostly by the respective ethnic groups in the region where they had their bases. The inability of the political parties to transcend their ethno-regional bases, and their failure to reflect their ethnic interests in their debates of issues with national consequences, adversely 
affected their ability to serve as instruments of national unity. Here, the writer clams that despite the fact that the government has recognized the creation of ethnic political parties as a positive political measure to promote every ethnic group in the country to have a sense of belonging, but in contrast, the existence of ethnic based political parties and hasty mushrooming of ethnic sub-nationalist politics has constituted one impediment to the development of one strong national identity and to political integration in present-day Ethiopia. Hence, this kind of party establishment road map in the country has paved the way to a series of conflicts which resulted in major predicaments and disunity among various ethnic groups in the country in general and regional states in particular.

\section{Elevated Ethnic Fundamentalism and Its Effect on Unity: Analyzing Pre-BGPDP Formation in BGRS}

In multi-ethnic democratic states, fostering unity means not only sharing identical political philosophy among individuals or groups, but it also remind us that individuals or groups may have differences in opinion and leaning. As stated above prior to the formation of BGPDP the region was led by a common front called BGPDUF which is a coalition of five ethnic-based political parties namely Shinasha People's Democratic Movement (SPDM), Benishangul People's Liberation Movement (BPLM), Gumuz People's Democratic Organization (GPDO), Mao People's Democratic Movement (MPDM) and Komo People's Democratic Movement (KPDM). It is actual fact that during the formation of BGRS none of the political party arrangements was done with the idea of nurturing ethnic solidarity out of ethnic diversity among the groups under the regional state. Every ethnic group's political parties were done out of necessity for a particular ethnic group, and not on the basis of ethnic solidarity or unity in the region.

Political opportunism is the hallmark of every ethnic political action in BGRS. Since in BGRS in particular and other multi-ethnic regional states in general no ethnic group trust each other as such, it becomes expedient for a political machinery to build coalition with certain political groups within other ethnic societies, with the sole aim of capturing power at the regional level. Beside this, always every little political opportunity among the people either from the indigenous ethnic groups of the region and others has prioritized to support their respective ethnic agenda and political interest only. Hence, with the prevalence of ethnic mistrust between the indigenous ethnic groups themselves as well as between indigenous and non-indigenous ethnic groups in the region, so in this regard the level of solidarity between the ethnic groups cannot in any way be considered to be cordial. There is no harmonious relationship between the indigenous ethnic groups and non-indigenous ethnic groups in the region. There is a great deal of mistrust running across various ethnic groups in the region. Thus, the political relationship existed among inter-indigenous ethnic groups and also between indigenous and nonindigenous ethnic groups remained an artificial alliance without firm direction.

Under BGRS territorial administration EPRDF and its member parties are labelled as BGPDP affiliated parties. Whereas, at the federal level and under EPRDF member party regional states administration (such as in Tigray, Amhara, Oromia and the Southern Ethiopia) BGPDP becomes affiliated party to EPRDF and its member parties. Currently, all EPRDF member parties such as ANDM, OPDO, TPLF and SEPDM opened their own respective offices in BGRS. In this regard, in November 2005, a Memorandum of Understanding was signed between EPRDF and the affiliated parties to manage the overall inter-party relationship exist between them (Asnake Kefale, 2009: 255-256). In fact, in December 2015 this document was revised.

However, some interview respondents blamed that sometimes some EPRDF representatives directly or indirectly involved in BGPDP activities. In fact, formal and informal engagement of EPRDF in BGPDP activities has its own reasons. The first reason is lack of awareness among some top leaders of BGPDP concerning the scope of their power in the region under federal political system of government. Interview respondents confirmed that when critical meeting and evaluation has been conducted among BGPDP members some leaders of the EPRDF are invited informally and formally by the consent of BGPDP. This indicates that how much BGPDP is weak and depend on EPRDF. The second fundamental reason is the prevalence of internal political disagreement which arises sometimes among indigenous ethnic groups political elites basically to seize power on behalf of its own ethnic groups in which the trend is inherited from the formerly existing individual ethnic group's political parties. Therefore, in this context, the relationship between BGPDP and EPDRF is not considered as genuinely a mutual partnership but practically there is some symptoms of superior-inferior relationships in the region's political dynamics.

Therefore, the political coalition that operates among the indigenous ethnic groups does not practically translate into ethnic alliance or understanding. It would be expected that, if such political understanding could work among the indigenous nationalities, then there should be no worry as to the possibility of a strong ethnic unity in the political life of the region at this time. In fact, the challenge of ethnic solidarity is not peculiar to BGRS alone, the problem is also prevailing in other multi-ethnic regional states of the country. The political disharmony that existed among indigenous ethnic nationalities during pre-BGPDP was derived from the very fact that the people of these nationalities do not see nor regard each other as the same or equal in the regional political dynamics.

The above stated claim is also substantiated by information gathered through interview. Information gained 
through interview reveals that prior to the ethnic based political parties' unification, everything that happened in the political system was given primarily ethnic colour and interpretation within the region (Interview conducted with BGPDP politicians 2017, Assosa). The idea of competence, ability to lead the region responsibly was ignored by the politicians and individuals in the region. This scenario has created problems of political animosity between the politicians in the region (ibid). It also created problems of ethnic unity among the indigenous ethnic groups and others (ibid). Indeed, an issue that was purely a party problem became overnight a regional issue. Most of the politicians profess and proclaim the interest of their respective ethnic group only (ibid). As mentioned already, the ethnic groups do not have any more trust vis-à-vis each other (ibid).

In fact, after the establishment of BGPDP, inter-ethnic relationships among indigenous ethnic groups in some extent improved. However, yet, sometimes internal political disagreement has been arising among indigenous ethnic group's political elites. As stated above, this has been happening because of individual's interest to seize power on behalf of its own ethnic groups in which the trend is inherited from the formerly existing individual ethnic group's political parties. There is no belief that an individual from a certain ethnic group could represent effectively the overall interest of another ethnic group within the political arrangement of the region (ibid). The argument here is that, it is an established trend by the respective ethnic groups not to allow any mix in terms of political representation within their particular locality homelands. But then, the problem is not that of quality representation, but the situation is purely that of ethnic intolerance in the region.

The political division of BGRS into five ethnic based parties significantly affected the fortunes and unity of the indigenous ethnic groups in the region. Accordingly, the Bertha ethnic group complained about the Shinasha ethnic group domination in public service institutions of the region, on the other hand members of Shinasha ethnic group also lamented about the domination of key political positions of the regional state by the Bertha and Gumuz ethnic groups. In this regard, the Shinasha ethnic group always based their argument on the fact that all available high and sensitive political offices are usually shared by individuals from the respective Gumuz and Bertha ethnic groups. So, the control of the sensitive political offices by Gumuz and the Bertha ethnic groups placed the Shinasha as a marginalised group in the region.

There is always lopsided attitude among those that occupied certain political positions in the regional government. The prevailing spirit of political party differences among indigenous ethnic groups during preBGPDP formation presented a loose regional consciousness. It is loose in the sense that, everybody feels for himself/herself and his/her immediate ethnic community, without considering the corresponding interest of other ethnic communities before BGPDP formation in the region. This indicates that those five indigenous ethnic groups are internally separated among each other in the regional political arena. In this regard, in a similar manner, ordinary individual who can be described as passive politician do not fundamentally connect to each other across the regional state at least as one people that share the same political goal. Indeed, in BGRS every ethnic groups are not accorded the same political treatment. Beyond this, extreme internal ethnic political indoctrination of the people by their own respective ethnic political party gradually produced the limited chance of any in-ethnic group believing in the capacity of out-ethnic groups to represent the interest of others in a political setting of the region.

However, the single act of making references to any individual through the ethnic affiliation of such a person is another point of a stratified political environment. People are identified only by their ethnic origin or card; irrespective of where such individual resides, or what the person is doing in the region. According to information gathered through interview that people had very little in common, because individuals from the five ethnic nationalities rarely discuss each other concerning the common good during BGPDF administration in the region. For instance, issues of advancing infrastructure in the region are usually relegated to the back bench during discussion. To seek for amenities that would ameliorate the suffering of the public at large is never considered as the first option. Basically the general assumption of the members of the Gumuz and Bertha ethnic nationalities in the regional politics has been that, whichever ethnic group that produces the regional president, stands as the most powerful ethnic group among the two (Interview conducted with BGPDP politicians 2017, Assosa). In fact, in a similar vein, this assumption was also prevalent in other indigenous ethnic groups of the region during BGPDF administration of the region.

It was actual fact that the motivation for most politicians from each ethnic groups in the region is centred on the premise of power and influence, and not necessarily in a bid to correct the anomalies within the various communities in the region. Each indigenous ethnic groups in the region does not want outside his respective ethnic group member to rule him/her homeland locality. In fact, in contemporary Ethiopian federal political setting the same scenario is played all over other ethnic nationalities in the country. It looks like that ethnic interest is placed above the national internal interest under present-day Ethiopia in general. Decision on certain issues of national implication are not visited or considered earnestly by the regional states in the country.

Therefore, absence of any coordinated national political agenda creates a loophole in the effort to create an enduring democratic environment which promote unity in diversity in the country in general and regional states in particular. Bringing political programmes which is fundamentally shaped by ethnic interest to the national 
level endangers the gradual transformation of the country towards multicultural federal democracy. The ethnic posturing which every of the ethnic groups are brandishing will in no way reduce the overbearing influence of ethnic identity based politics in the country. Even within a given political party, nationally people hide under the pretense of a resolve to build a national coalition, but separately each group plots how to hijack, dominate, or secure a particular political position for their ethnic group in the country. In fact, in the contemporary Ethiopian federal political arrangement, ethnicity has become a prominent issue so that in the contest for power, the political actors consider ethnicity as the major weapon to gain ascendancy.

In reality, when political parties are organized only through the political lens of ethnic identity card either at the federal or regional levels of government, the quest for the control of various political or public offices at different levels of government has remained a product of ethnic political agenda. And also when initiatives are drawn and pursued for implementation through ethnic consideration or when appointment is made to be under the prerogative of ethnic identity card at the expense of one's qualification and capability can have a potential to produce gradually extreme ethnic fundamentalism among individuals. In this regard, for instance, the prominent scholar Horowitiz (1985:291) clearly argued that societies that are deeply riven along a preponderant ethnic cleavages tend to throw up party systems that exacerbate ethnic conflicts. By appealing to electorates in ethnic terms, by making ethnic demands on government, and by bolstering the influence of ethnically chauvinist elements within each group, parties that begin by merely mirroring ethnic divisions help to deepen and extend them (ibid). Accordingly, an ethnically based party derives its support overwhelmingly from an identifiable ethnic group and serves the interests of that respective group (ibid).

Therefore, this kind of political road map utilized to organize political parties has not been helpful in any way to enhance sustainable unity and democratic effort of the country in general and BGRS and other regional states in particular, rather in contrast it has created elevated ethnic chauvinism or ethnic fundamentalism and accordingly it has confronted the unity of BGRS. And latter it also opened the door for politicians and individuals to play lopsided proxy ethnic political game within the neighbouring regional states and consequently this situation tend to boundary dispute and ethnic conflict. In this regard, BGRS is one of the favorable region to play proxy ethnic political game by the neighbouring regional states political actors.

Figure 4.The Panorama of Ethnic Conflict in Contemporary Ethiopian Federal Political Arrangement

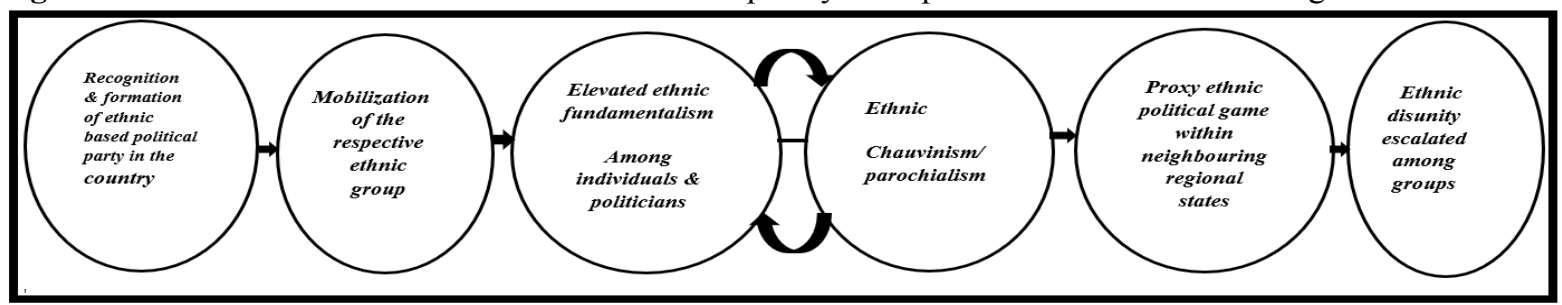

Source: This diagram is developed by the researcher

In this regard, this study attempted to explore the effect of ethnic chauvinism on regional unity by distributing survey questionnaire. Accordingly, the survey results clearly affirm that currently the existence of ethnic chauvinism has been perceived as one major source to ethnic disunity in BGRS. In this regard, for instance, the results in the table 4.1 below show that a significant majority $(68.1 \%)$ of the participants agreed that the prevalence of ethnic chauvinism in BGRS is perceived as one issue which is endangering the ethnic unity in the region, however few respondents $(27.2 \%)$ did not agree that this is a source to regional ethnic disunity in the region. for further information refer the following table 4.1 below.

Table 4.1. Showing the Opinion of Respondents Regarding the Existence of Ethnic Chauvinism/Bigotry vis-àvis Ethnic Unity in BGRS.

\{QUESTION\}: In your perception, the existence of ethnic chauvinism/bigotry is perceived as one major issue endangering ethnic unity in BGRS?

\begin{tabular}{|l|l|r|r|r|r|}
\hline & \multicolumn{2}{|c|}{ Frequency } & Percent & Valid Percent & Cumulative Percent \\
\hline \multirow{5}{*}{ Valid } & Strongly agree & 171 & 45.1 & 46.6 & 46.6 \\
\cline { 2 - 7 } & Agree & 87 & 23.0 & 23.7 & 70.3 \\
\cline { 2 - 7 } & Undecided & 6 & 1.6 & 1.6 & 71.9 \\
\cline { 2 - 7 } & Disagree & 62 & 16.4 & 16.9 & 88.8 \\
\cline { 2 - 6 } & Strongly disagree & 41 & 10.8 & 11.2 & 100.0 \\
\cline { 2 - 6 } & Total & 367 & 96.8 & 100.0 & \\
\hline Missing & System & 12 & 3.2 & & \\
\hline Total & & 379 & 100.0 & & \\
\hline
\end{tabular}

Source: Survey data, 2016-2017 
In this context, in addition to information gained through interview, this study attempted to explore the outcome of the existence of ethnic based regional political parties by distributing survey questionnaires. Accordingly, the survey results clearly affirm that currently the existence of ethnic political parties has been perceived as one major source of ethnic disunity in BGRS. In this regard, for instance, the results in the table 4.2 below show that a significant majority $(68.1 \%)$ of the participants agreed that the existence of ethnic based political parties in BGRS is perceived as one major source of regional ethnic disunity, however few respondents $(27.2 \%)$ did not agree that this is a source to regional disunity in the region.

Table 4.2. The Opinion of Respondents Concerning the Existence of Ethnic Based Regional Political Parties visà-vis the Feature of Ethnic Unity in BGRS

\{QUESTION\}: In your opinion, currently the existence of ethnic based regional political parties are considered as the source of disunity in BGRS?

\begin{tabular}{|l|l|r|r|r|r|}
\hline & Frequency & Percent & Valid Percent & Cumulative Percent \\
\hline \multirow{5}{*}{ Valid } & Strongly agree & 166 & 43.8 & 45.2 & 45.2 \\
\cline { 2 - 6 } & Agree & 106 & 28.0 & 28.9 & 74.1 \\
\cline { 2 - 6 } & Undecided & 20 & 5.3 & 5.4 & 79.6 \\
\cline { 2 - 6 } & Disagree & 48 & 12.7 & 13.1 & 92.6 \\
\cline { 2 - 6 } & Strongly disagree & 27 & 7.1 & 7.4 & 100.0 \\
\cline { 2 - 6 } & Total & 367 & 96.8 & 100.0 & \\
\hline Missing & System & 12 & 3.2 & & \\
\hline Total & & 379 & 100.0 & & \\
\hline
\end{tabular}

Source: Survey data, 2016-2017

In summary, organizing political parties only through the political lens of ethnicity either at the federal and regional levels of government would gradually create lopsided elevated ethnic fundamentalism, chauvinism and parochialism among politicians and individuals. Later on, this condition will tend to generate ethnic conflict and tension among the groups.

\section{Ethnic Loyalty and the Nature of Politics during BGPDUF Administration of BGRS}

During BGPDUF administration of the region every ethnic group in BGRS; be it from the indigenous or nonindigenous plays politics that is tended to benefit their individual ethnic groups. The politics of we and them is so substantiated by the political behaviour of all ethnic nationalities within their homeland area and outside their homeland locality. The individuals from these various nationalities do consider first a political party that has a strong ethnic background. Individuals who are resident in other ethnic homelands either for business or trade, as employees of a federal government agency, or as an employee in a private enterprise are not in any way separated from the political nature in his ethnic homeland locality. It is actual fact that in multi-ethnic state nobody wants to see his ethnic group disadvantaged.

During BGPDUF administration of the region, indigenous ethnic groups were always busy by articulating their strategies on how to capture the most influential positions of the regional government. It does not matter to them, if their individual political programme will be of benefit to the entire region or not. What to them is of most importance is the end result of their plans, which is to have someone of their ethnic stock controlling the government or at least holding some powerful regional positions in the regional government. There is no longer a hidden secret here that the voting pattern in BGRS and other regional states were dictated more by sentiments and emotions predicated on ethnic attachment and to an extent, individual recognition rather than regional unity and ideological development. Therefore, ethnic choice determines the political direction of individuals during regional election. In this regard, each members of the respective political parties believe that, it is the only chance available for them to develop their own respective community, and also to advance their political relevance in the area. Hence, the widespread thinking among politicians and individuals was that whoever holds higher regional positions will certainly concentrate infrastructural development in his/her own ethnic area.

Thus, pressure exerted on the political office holders from their respective ethnic group was high. And this situation hinders their independent judgment on how best to administer the region. When anybody occupies any political position in the region, there was always the claim of ethnic domination. Here, there is no doubt that elevated ethnic loyalty may produce intolerant strains and can also cause exclusion of other ethnic groups. It is actual fact that many individual within the indigenous ethnic groups mentioned his or her ethnic nationality first, then followed by the name of the village such an individual hails from. Every individual, no matter his/her ethnic origin places a very strong emotional attachment to issues concerning his/her own ethnic group. So, at this juncture, it seems that ethnic loyalty in most cases takes superior position in the regional political arena. Irrespective of individual level of academic intelligence, or exposure, what comes to an individual thought remains always the ethnic identity card of such an individual. 


\section{The Dynamics of Ethnic Unity in BGRS: Brief Evaluation of Post-BGPDP Formation 6.1 The Central Political Debate among the Politicians Concerning Party Amalgamation}

The aftermath of the regional presidential power shift from the Gumuz ethnic group to the Bertha ethnic group, the leaders of each ethnic group political parties and common front leaders with the extensive help of EPRDF called in a conference at Woreta town of Amhara regional state aimed at providing a political training to the political leaders and some members of each ethnic parties how to strengthening 'unity out of diversity' in BGRS. As interviews conducted with high officials of the region reveal, the basic object of the conference was how to encourage regional unity in diversity. In this context, the main question posed at the conference was why each ethnic groups of the region go with separate ways? (Interview conducted with officials and experts of office of BGPDP Central Committee, Nov, 2016).

At the heart of this question there are two main arguments posed by the conference participants such as (1) Those that advocate the amalgamation of each ethnic based regional parties in to one party claim that amalgamation can promote regional ethnic unity and (2) Those that oppose the amalgamation of each ethnic based regional parties in to one party can endanger regional ethnic unity (ibid). Would regional unity be strengthen through the amalgamation of each ethnic based regional parties in to one party or not? The interview reveal that on these issues some participants of the conference accept the amalgamation while, some few participants oppose the amalgamation. The central claim of the opponents of the amalgamation was:

Amalgamation from each ethnic based regional parties in to one party will create disparity among the ethnic groups since some ethnic groups are well educated while others are not. Hence, the amalgamation might foreshadow an eventual dissolution of the regional unity, that would be very difficult, if not it is impossible to accomplish regional unity (ibid).

But the proponents of the amalgamation believe that it will create regional unity. They claim that the current challenges to promote unity in the regional state would be because some political leaders of the distinct ethnic group parties within the region would create the grievances of the regional community caused by the failure of the political leaders to shoulder their responsibility properly (ibid). Some leaders of the distinct ethnic parties used the party as a cave whenever they create good governance problems within the region. In this context, proponents claim that one major fundamental internal threat to the unity of the regional state is the existence of individual ethnic based political parties in the region. Since, practically their major objective is to promote their own selfish interest rather than the promotion of regional unity (ibid). Therefore, they argued that creating party unification is one critical step to enhance regional unity in BGR.

Based on the foregoing arguments, one of the best ways to ensure regional unity is through institutions that have the capacity to instil a sense of collective regional identity among the ethnic groups of the region. This would necessarily involve how to harness and nurture the diverse groups within the region to feel being part of the BGRS. As interview conducted with members and party leaders of BGPDP the main reason why individual ethnic based political parties decide to make a bargain and establish one party known as Benishangul-Gumuz People's Democratic Party (BGPDP) is the hope to promote the regional unity within diversity and to solve sources of good governance problems executed by party members and leaders of individual ethnic based political parties in the region.

As interview conducted with former party leaders of BGPDP reveal that, even if there is no ideological or policy differences between those two political parties in Benishangul-Gumuz regional state, under the regime of BGPDUF some members and leaders of each ethnic group's political parties promote their own individual interest to seize and sustain political power on behalf of its own respective ethnic group as a result it very difficult to endorse the expected good governance in the region. Hence, to realize the unification or amalgamation of those ethnically diversified political parties in to one party (BGPDP), EPDRF played remarkable roles in Benishangul-Gumuz regional state by providing various short term training to the members of each individual ethnic party members concerning the relevance of the unification in the region (Interview conducted with officials and experts of office of BGPDP Central Committee, Nov, 2016).

\subsection{Evaluating the Role of Regional Based Political Parties in Fostering Regional Ethnic Unity in BGRS}

In democratic states, political parties must serve as a guide to creating regional or national unity. Political parties are supposed to be capable institutions for prompting regional as well as national unity in multi-ethnic states. They are supposed to serve as bridge between the contending ethnic nationalities, but this function has been abdicated basically by the politicians in BGRS. Indeed, the parties and their officials are deeply aware that unity is supposed to serve as a channel through which the bitter and secret conspiracy thriving within the political scene could be reduced to a negligible level, if not totally stamped out from the political life of the region

In fact, it is inevitable reality that in multi-ethnic federations diversities should be recognized as a basis to promote unity in diversity. Thus, each of the regional political parties should do so to reflect their own diversities because it is important for promoting regional unity. Regional unity means recognising all the component parts of a nation and attending to their needs and they too making sacrifices in the interest of the nation. Which means 
it is possible for political parties to achieve unity in diversity by recognising and promoting the various ethnic nationalities within its territory. Actually, as stated elsewhere in this thesis, in multi-ethnic federal states it is quite clear that the need for national or regional unity achieved only when different ethnic cleavages are recognized and fairly represented within various institutions.

With this assumption, the FDRE constitution aims to promote unity in diversity, but the reality on the ground in the contemporary Ethiopian situation betrays the tendency of various politicians and individuals either at the federal levels of government and regional states go in the opposite direction, thereby jeopardising the constitutionally entrenched spirit of promoting unity in diversity within the country in general and regional states in particular. In this regard, at the time of party unification various individuals, politicians, and non-active politicians in BGRS would begin to argue on the need for the political parties to consider individuals personalities rather than considering the mere loyalty of individuals to the party from each ethnic groups to maintain sustainable regional unity in diversity. In this regard, in fact as stated above, there is a little bit improvement after the establishment of BGPDP but it is not as such realized as the promise.

Therefore, during national and regional elections the main promises and political hopes prevailing in the country in general and regional states in particular is enhancing unity. But immediately the national and regional elections are over, these political hopes of promoting unity are diverted. Those elected individuals usually sit back and concentrate only on how to recoup the political power. It is actual fact that political talks and promises about national and regional unity usually perish immediately after the conclusion of each elections (FGDs with various community, 2017). Hence, it seems like that all these positive promises and hopes done during elections are only to generate political sympathy rather than promoting unity among the ethnic groups. Individuals from the indigenous ethnic nationalities usually believe that anyone that occupies certain political position of regional government will develop his/her own ethnic locality or homeland at the expense of other ethnic nationalities. Actually, the main source of this assumption is the individuals elevated primordial attachment to his/her own ethnic group.

In this context, beyond information derived through interview, this study has attempted to examine the role of regional political parties in promoting unity in diversity under BGRS by distributing survey questionnaires. Accordingly, the survey result clearly testifies that currently the regional political parties are not promoting regional unity, rather they are playing the game in opposite direction under the region. In this regard, for instance, the results in the table 4.3 below show that a significant majority $(71.8 \%)$ of the participants agreed that the existence of ethnic based regional political parties in BGRS is perceived as one major source of regional ethnic disunity, let alone promoting unity. However, very few respondents $(19.8 \%)$ did not agree that this is a source to regional disunity in the region.

Table 4.3. The opinion of respondents concerning the existence of ethnic based regional political parties vis-àvis the feature of ethnic unity in BGRS

\begin{tabular}{|c|c|c|c|c|c|}
\hline & & Frequency & Percent & Valid Percent & Cumulative Percent \\
\hline \multirow{4}{*}{ Valid } & Yes & 137 & 36.1 & 36.1 & 36.1 \\
\hline & No & 184 & 48.5 & 48.5 & 84.7 \\
\hline & Neutral & 58 & 15.3 & 15.3 & 100.0 \\
\hline & Total & 379 & 100.0 & 100.0 & \\
\hline
\end{tabular}

Source: Survey data, 2016-2017

The main reason why regional based political parties are not playing essential role in promoting regional unity under BGRS were also prompted through an open-ended question on the survey questionnaire. In this regard, the following are few quotes from what respondents had explained in their own words in response of the question why the regional political parties are not playing appropriate role in promotion of unity in BGRS.

- "In our regional state one major causes that makes the people are not trusting the government is the problem of current ruling party of the region because during election the ruling party considered itself as the only party that serve properly and hold the regional people together".

- "Political parties that stipulated the fact concerning the governance problem in the region were isolated by the regional ruling party. This issue in its part challenges the unity and democratic culture of the community in the region".

- "After holding the political position everybody feels his/her relatives and ethnic groups no more value for others. Beyond this, they didn't considered us as the citizen of the country they don't care about others rather than their own ethnic group".

- "The existing political parties in the region served only to the benefit their own respective ethnic group rather than others".

- "It is illogical to claim that ethnic and lineage based political parties can nurture unity, rather they can 
open the door to egoistic thinking among the community".

- "At this juncture, it is very difficult that ethnic based political parties can give value to other ethnic groups because they always give priority to their own ethnic group".

- "In reality the existing political parties in the region are not practically promoting unity in diversity, rather they are indorsing ethnic fundamentalism, ethnic chauvinism and parochialism".

- "In BGRS ethnic based political parties are propagating hatred instead of unity among the ethnic groups to hold the political power in the region".

- "....for instance, instead of democratically confronting the regional ruling party/BGPDP, GPDM is busy with the act of violating other ethnic group's human and democratic rights in the region”.

- "In fact, normatively they are organized as political parties in the region but practically their act is not make them as political parties because they are doing only for their own personal advantage and their own families nothing they are doing to enhance unity in diversity in the regional state".

- "The regional ruling party/BGPDP is not positively approached and accepted some ideas of the opposition political parties in the region. The regional ruling party assumed that I am the only party which is essential to this regional state”.

- "Every political parties in BGRS have extreme local thinking rather than endorsing unity in the region".

- "Actually, rather than creating harmony the ruling and opposition political parties are doing to create disunity and conflict among the ethnic groups in the region".

Therefore, based on the above information, here it can be argued that regional based political parties of BGRS are not appropriately playing the country's constitutional sprit of promoting unity in diversity in different areas of the country.

\section{Concluding Remarks}

It is actual fact that organizing political parties only through the political lens of ethnicity would gradually create lopsided elevated ethnic fundamentalism, chauvinism and parochialism among politicians and individuals. Later on, this condition will tend to generate ethnic conflict and tension among the groups under multi-ethnic states. For instance, information gained through different instruments evidently indicates that the constitutional promises and hops of the spirit of promoting unity in diversity is threatened by various politicians and individuals in BGRS. Individuals either from the indigenous ethnic nationalities and non-indigenous ethnic groups usually believe that anyone that occupies certain political position of regional government will develop his/her own ethnic locality or homeland at the expense of other ethnic nationalities. Therefore, the reality on the ground in BGRS betrays the tendency of various politicians and individuals are jeopardising the constitutionally entrenched essence of promoting unity in diversity in the region. In this regard, regional based political parties are not properly playing the required role in promoting unity in diversity in BGRS in general. This is happened because of absence of strong and competitive regional based opposition political parties in the region.

\section{Recommendations}

In contemporary Ethiopia the ruling political parties at the federal and regional states are designed basically through the political lens of ethnic ideology platform. Actually, this type of political road map which we have recognized and applied in the country in general and regional states in particular initially created elevated ethnic fundamentalism, ethnic chauvinism and parochialism among individuals and politicians. And later on it also opened the door for politicians and individuals to play proxy ethnic political game within the neighbouring regional states and consequently this condition gradually led to boundary dispute and ethnic conflict. This situation itself is negatively affecting the peaceful coexistence among ethnic groups in Ethiopia in general and BGRS and other regional states in particular. In this context, this study found that the constitutional promises and hopes of the spirit of promoting unity in diversity is threatened by various politicians and individuals in BGRS. Therefore, there is need to change the way political parties are organized in Ethiopia in general and regional states in particular. In this context, political party formation proclamation should be reviewed because it does not ban the formation of ethnic based political party in the country. In view of that, federal and regional based political parties should be made to come together and sign a code of conduct which must be monitored by independent observers providing that using ethnicity to divide people is not acceptable in the country in general and regional states in particular. In addition to this, organizing strong, competitive and all inclusive regional based opposition political party is necessary to strengthen democracy in the region.

\section{References}

Apparodai, A. (1968). The Substance of Politics. OUP, London.

Asnake, K. (2009). Federalism and Ethnic Conflict in Ethiopia: A Comparative Study of the Somali and Benishangul-Gumuz Regions, New York: Routledge.

Burgess, M. (2006). Comparative Federalism: Theory and Practice. Abingdon, Oxon: Routledge. 
Duchacek, I.D. (1970). Comparative Federalism: The Territorial Dimension of Politics, New York: Holt, Rinehart, \& Winston.

Horowitz, D. (1985). Ethnic Groups in Conflict . California: University of California Press.

Ubani, C. (2014). Political Parties and National Integration: An Assessment of the Nigerian State since Independence. Covenant University Journal of Politics and International Affairs (CUJPIA), Vol. 2, No. 2, $31-44$.

Young, J. (1999). 'Along Ethiopia's Western Frontier: Gambella and Benishangul in Transition'. The Journal of Modern African Studies, Vol. 37: 321-346.

\section{Legal Documents}

The Constitution of the Federal Democratic Republic of Ethiopia Proclamation No. 1/1995, Federal Democratic Republic of Ethiopia (Addis Ababa, 1995).

The Constitution of the Benishangul-Gumuz Regional state, Lissane Hig Gazeta of the Benishangul-Gumuz Regional state, 1th Year No 1 Asossa, July 1996

The Revised Constitution of the Benishangul-Gumuz Regional state, Lissane Hig Gazeta of the BenishangulGumuz Regional state, 8th year No. 4, Asossa, 02 December 2002.

Gumuz People Democratic Movement (GPDM) party establishment regulation.

Benishangul-Gumuz people Democratic Party (BGPDP) party establishment regulation.

The Revised Political Parties Registration Proclamation No. 573/2008 of Ethiopia. 